\title{
Correction: Attenuated Recombinant Influenza A Virus Expressing HPV16 E6 and E7 as a Novel Therapeutic Vaccine Approach
}

\author{
Christoph Jindra, Bettina Huber, Saeed Shafti-Keramat, Markus Wolschek, Boris Ferko, \\ Thomas Muster, Sabine Brandt, Reinhard Kirnbauer
}

There is an error throughout the Methods section of this manuscript. The virus concentration is recorded incorrectly as $3.75 \log \mathrm{TCID}_{50}$. The correct concentration is $7.2 \log \mathrm{TCID}_{50}$.

\section{Reference}

1. Jindra C, Huber B, Shafti-Keramat S, Wolschek M, Ferko B, Muster T, et al. (2015) Attenuated Recombinant Influenza A Virus Expressing HPV16 E6 and E7 as a Novel Therapeutic Vaccine Approach. PLoS ONE 10(9): e0138722. doi: 10.1371/journal.pone.0138722 PMID: 26381401

Citation: Jindra C, Huber B, Shafti-Keramat S, Wolschek M, Ferko B, Muster T, et al. (2015)

Correction: Attenuated Recombinant Influenza A Virus Expressing HPV16 E6 and E7 as a Novel Therapeutic Vaccine Approach. PLoS ONE 10(11): e0143269. doi:10.1371/journal.pone.0143269

Published: November 12, 2015

Copyright: $\odot 2015$ Jindra et al. This is an open access article distributed under the terms of the Creative Commons Attribution License, which permits unrestricted use, distribution, and reproduction in any medium, provided the original author and source are credited. 